\title{
Basal Testosterone Secretion and Response to Human Luteinizing, Follicle-Stimulating, and Growth Hormones in Culture of Cells Isolated from Testes of Infants and Children
}

\author{
ESPERANZA BERENSZTEIN, ALICIA BELGOROSKY, MARíA TERESA G. DE DÁVILA, AND \\ MARCO A. RIVAROLA
}

Laboratorio de Investigación, Hospital de Pediatría Garrahan, Buenos Aires, Argentina

\begin{abstract}
Little is known on the hormonal regulation of the early postnatal phase of Leydig cell activation in the human. Testosterone secretion by prepubertal testicular cells in culture was studied in two different age groups, 0-7-mo-old (group 1) and 16-36-mo-old (group 2) boys. A mixed cell preparation was isolated from testes collected at necropsy and maintained in culture for $6 \mathrm{~d}$. Cells were cultured in serum-free medium in basal conditions and under the stimulation of human $(\mathrm{h}) \mathrm{LH}$, $\mathrm{hFSH}$, or recombinant $\mathrm{hGH}$, and the secretion of testosterone was determined on $\mathrm{d} 6$ by RIA. In basal conditions, cells of group 1 secreted more testosterone (median $5.83 \mathrm{pmol} / 10^{6}$ cells $\cdot \mathrm{d}, n=$ 7) than cells of group 2 (median $1.73, n=5$ ), $p<0.05$, reflecting the steroidogenic potential of the testes in vivo. Under hLH stimulation, cells of group 1 responded by increasing testosterone secretion significantly. Surprisingly, hFSH stimulation elicited a similar response in cells of group 1. Because FSH receptors are presumably located in Sertoli cells, it is concluded that these cells secreted a paracrine factor that stimulated testosterone secretion
\end{abstract}

by Leydig cells. On the other hand, recombinant hGH also stimulated the secretion of testosterone by cells of group 1 . Recombinant hGH could have interacted with either $\mathrm{GH}$ or prolactin receptors of testicular cells. Cells of group 2 did not respond to any stimulus. Because serum levels of LH, FSH, GH, and prolactin are higher during the first months of life than later in childhood, it is possible that the early postnatal activation of the testis is under multiple pituitary hormone influence. (Pediatr Res 38: 592-597, 1995)
hLH, human LH
hFSH, human FSH
rhGH, recombinant hGH
hCG, human chorionic gonadotropin
PRL, prolactin
H\&E, hematoxylin and eosin

Abbreviations
The developmental history of human Leydig cells is a triphasic event: fetal, neonatal, and pubertal (1). Three peaks in serum testosterone levels have been described, viz., during the first half of gestation when the genitalia are formed (2); soon after birth, peaking at 2-3 mo (3); and at puberty (4). The biologic significance of the early postnatal phase of Leydig cell activation remains a matter of speculation. Androgen secretion after birth may influence the development of the sexually dimorphic nucleus of the preoptic area in the hypothalamus (5). Sex hormones are involved in the control of male behavior in the rat, and the sensitive period for this effect is embryonic and ends by d 6 postnatally (6). Finally, blocking gonadotropic

Received August 3, 1994; accepted March 27, 1995.

Correspondence and reprint requests: Esperanza Berensztein, Laboratorio de Investigación, Hospital de Pediatría Garrahan, Pozos 1881, Buenos Aires Argentina (1245).

Supported by grants from the Consejo Nacional de Investigaciones Científicas y Técnicas (CONICET) of Argentina, the World Health Organization, and Programa Latinoamericano en Reproducción Humana (PLACIRH). secretion by treatment of male monkeys with a gonadotropicreleasing hormone agonist for the first 4 mo of postnatal life alters differentiation of CNS centers that regulate sexual and skeletal development (7), as well as adult sexual behavior (8).

Mature Leydig cells are present after birth in man but they regress during the first 6 mo of life (9). In most studies, postnatal Leydig cells have been regarded as remnants of the fetal Leydig cell population $(10,11)$. It is interesting, however, that the regression of Leydig cells after the 18th week of fetal life is interrupted by a pronounced rise in the number of fetal Leydig cells in the 3rd mo after birth, and it is followed by a rapid decrease in such numbers afterward (9).

Little is known about the endocrine-paracrine control of this early postnatal activation of the testes. Because serum $\mathrm{LH}$ is increased during the first months of life in boys (12), pituitary $\mathrm{LH}$ is probably involved in the regulation of the postnatal elevation in circulating testosterone. Serum FSH has also been found to be increased in early infancy, particularly in girls (12). 
On the other hand, the sex difference in the concentrations of serum LH and FSH reported in the early postnatal period could be due in part to steroid and peptide secretions by the infantile human testis. High serum levels of GH and PRL (13) have been described during the first days of life (13-15). Values decrease afterward, but they are still high at $8 \mathrm{wk}$ compared with adult concentrations (16). Furthermore, by extension to what has been found in numerous in vivo and in vitro studies, Leydig cell function might be modulated by many other peptide and nonpeptide hormones and factors, including insulin, IGF-I, and transforming growth factor $\beta$ (17). Many of these factors are produced by the local cell population, acting in a paracrine fashion. Cell population in the testes of infants differs greatly from that of adults because of the absence of mature Sertoli cells and mature spermatogenesis. Therefore, paracrine influences might also be expected to be different.

We have developed a method for maintaining in culture prepubertal human testicular cells isolated from testes collected at necropsy (18). We have demonstrated that these cells are able to survive in culture in good functional condition and to maintain testosterone secretion for more than $7 \mathrm{~d}$.

The present study was undertaken, $l$ ) to compare testosterone secretion in cultures of cells obtained from infants (10-dto 7-mo-old boys) with that of cells from 16-33-mo-old boys, and 2) to study the effect of hLH, hFSH, and rhGH stimulation on testosterone secretion by these cells.

\section{METHODS}

Hormones. hLH (NIDDK-hLH-B-1 AFP-0642 B) and hFSH (NIDDK-hFSH-I-SIAFP.1 AFP-5720 D), highly purified by selective immunoaffinity, free of immunoreactive LH, TSH, GH, or PRL, were kindly provided by the National Institute of Diabetes and Digestive and Kidney Diseases (NIDDK). Recombinant hFSH (Gonal F) was a gift of SERONO Argentina S.A. Recombinant hGH (Genotropin) from $\mathrm{KABI}$, was kindly provided by ASTRA Laboratories of Argentina.

Clinical Material. Testicular cells were isolated from testes collected at necropsies of 10-d- to 36-mo-old patients who had died because of disorders not related to endocrine or metabolic diseases. The study was approved by the Research Committee of the Hospital de Pediatría Garrahan of Buenos Aires. For data analysis patients were divided in two age groups on the basis of presence or absence of Leydig cells in testicular biopsies: group 1 ( $n=7$ ) 10-d- to 7-mo-old boys, median $3 \mathrm{mo}$; this age includes the whole postnatal period of Leydig cell activation, and group 2 ( $n=5), 16-36$-mo-old boys, median $33 \mathrm{mo}$, the age period which corresponds to part of the quiescent stage of testicular development in childhood. Diagnoses were the following: group 1, five cases of congenital heart diseases, one case of intracranial hemorrhage, and one of septic shock; group 2 , one case of congenital heart disease, two cases with abdominal tumors (one hCG-negative hepatoblastoma and one malignant mesenchymoma), one case of broncopneumonia, and one of meningitis.

Figure 1 shows histologic preparations of representative testes of the two groups of patients. The two subjects of group
1 had fetal-type Leydig cells and immature seminiferous cords. No mature Leydig cells could be recognized in patients of group 2, but Leydig cell precursors were observed.

Isolation and culture of human immature testicular cells. Routinely, cadavers were placed in a refrigerator within $1 \mathrm{~h}$ after death. Necropsies carried out up to $24 \mathrm{~h}$ after death were used for processing testes for cell isolation. To obtain a cellular suspension, in the 12 different experiments testicular tissue was processed as described previously (18). Briefly, after taking a small portion for light microscopy, testes were digested twice in $1.18 \times 10^{6} \mathrm{U} / \mathrm{L}$ collagenase for $20 \mathrm{~min}$ at $37^{\circ} \mathrm{C}$. Live cells were counted with a Neubauer's chamber using the trypan blue exclusion method. Between 30 and 50 million cells were harvested in each experiment. Cells were seeded at a density of $1 \times 10^{6} \mathrm{cell} / \mathrm{mL}, 0.5 \mathrm{~mL} / \mathrm{well}$, in 24 -multiwell culture dishes, resuspended in a chemically defined medium supplemented with $5 \mathrm{mg} / \mathrm{L}$ vitamin $\mathrm{C}, 0.2 \mathrm{UI} / \mathrm{L}$ vitamin $\mathrm{E}$, and $10 \%$ bovine fetal serum. Plates were placed at $37^{\circ} \mathrm{C}$ in a humidified atmosphere of $95 \%$ air, $5 \% \mathrm{CO}_{2}$. Forty-eight hours later the medium was removed, and the monolayer was washed twice with Hanks' solution. Fresh medium without serum was then added in triplicate (basal condition). Fresh medium with hFSH (16.8 UI/L), group $1(n=4)$, NIDDK in two studies, and Gonal F in the other two; hLH (40.1 UI/L), group $1(n=5)$, group $2(n=$ 4); and $\mathrm{rhGH}(0.12 \mathrm{UI} / \mathrm{L})$, group $1(n=5)$, group $2(n=4)$, was added in triplicate in separate wells. After $48 \mathrm{~h}, \mathrm{~d} 4$ of culture, media were removed and fresh media with and without hormones were added for another $48 \mathrm{~h}$. On d 6 of culture, conditioned media were collected. They were saved and stored at $-20^{\circ} \mathrm{C}$ for testosterone assay. Occasionally testosterone was determined on d 4 of culture. Cells were harvested after incubation with trypsin EDTA ( 0.5 and $0.2 \%$, respectively) for $3 \mathrm{~min}$ at $37^{\circ} \mathrm{C}$ and counted as above.

During culture, cells were observed using a ICM 405 Zeiss contrast phase microscope.

Histochemical staining of testicular cells in culture. The expression of cytokeratins in testicular cell monolayers was studied by immunohistochemistry (19). After removing the medium, cells were incubated at room temperature with the primary antibody (rabbit polyclonal antikeratin, 1/200 in $\mathrm{HCl}-$ Tris buffer) for $45 \mathrm{~min}$. After two washings, biotinylated pork anti-rabbit (1/300) IgG was added as secondary antibody, followed by avidin-biotin horseradish peroxidase conjugate (DAKO, Denmark). To obtain brown staining, 3,3'-diaminobenzidine tetrahydrochloride (D 5637, Sigma Chemical Co., St. Louis, MO) was used as a substrate $(0.05 \%$ in $\mathrm{HCl}$-Tris buffer, $0.01 \% \mathrm{H}_{2} \mathrm{O}_{2}$ ).

$3 \beta$-Hydroxysteroid dehydrogenase histochemical coloration was performed on $\mathrm{d} 6$ of culture following the procedure of Steinberger et al. (20). The cell monolayer was incubated for $90 \mathrm{~min}$ at room temperature in PBS containing $0.25 \mathrm{nmol} / \mathrm{L}$ nitro blue tetrazolium, $1.5 \mathrm{nmol} / \mathrm{L} \mathrm{NAD}$, and $0.4 \mathrm{nmol} / \mathrm{L}$ $3 \beta$-hydroxy- $5 \beta$-androstan-17-one.

Determination of testosterone. Testosterone was determined in conditioned media by RIA, in duplicate, using a testosterone MAIA Kit (BIODATA, Milan, Italy) as reported previously (18). The mean of three wells was calculated for 

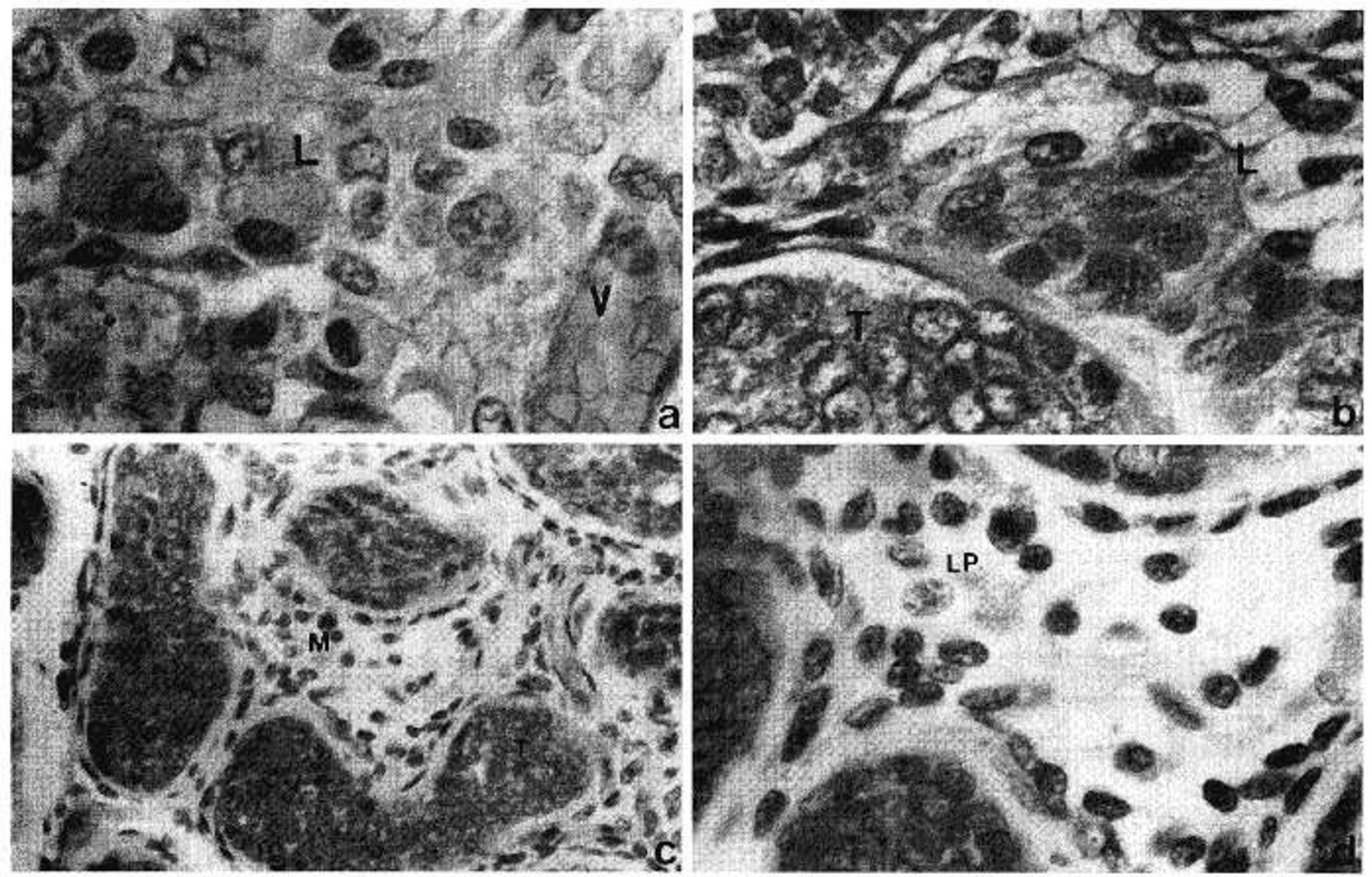

Figure 1. (Panel $A)$ Testis of a 10-d-old newborn. Fetal-type Leydig cells $(L)$ with abundant cytoplasm and ovoid nuclei can be seen near blood vessels $(V)$ (H\&E, $\times 100)$. (Panel $B)$ Testis of a 7-mo-old infant. Leydig cells $(L)$ are seen in scattered clusters surrounding tubules $(T)(\mathrm{H} \& \mathrm{E}, \times 40)$. (Panel $C)$ Testis of a 33-mo-old boy. Immature solid tubules $(T)$ populated by primitive Sertoli cells and undifferentiated mesenchymal cells $(M)$ in the interstitium are observed $(\mathrm{H} \& \mathrm{E}, \times 25)$. (Panel $D)$ Testis of another 33-mo-old boy. Mature Leydig cells could not be recognized but undifferentiated cell precursors $(L P)$ are present $(\mathrm{H} \& \mathrm{E}$, $\times 40)$.

each experimental conditions. Then, medians for each group were calculated, and differences between groups were compared by the test of medians (22).

\section{RESULTS}

Microscopic examination of monolayers. The presence of developing Sertoli cells and of steroidogenic cells in cultures was checked by light microscopy of histochemically stained cells. The expression of keratins was taken as evidence of the presence of Sertoli cell precursors (21). Evidences of immunospecific staining was observed in clusters of cells in culture (data not shown). However, not all Sertoli cells express keratins (21).

Staining for $3 \beta$-hydroxysteroid dehydrogenase was observed in fibroblast-like cells scattered around clusters of staining negative cells suggesting an organized arrangement of steroidogenic and nonsteroidogenic cells in culture (Fig. 2).

Testosterone secretion in culture. In basal conditions, secretion of testosterone into culture media was determined in every instance: the median of group $1(n=7), 5.83$ was significantly higher than the median of group $2(n=5), 1.73$ $\mathrm{pmol} / 10^{6}$ cells $\mathrm{d}, p<0.05$, test of medians.

The time course of cell secretion in culture was studied by determining testosterone on conditioned media of d 4 and 6 , under basal conditions and under hLH, hFSH, and rhGH stimulation, in cells collected from a 1-mo-old subject (Table 1). In every instance testosterone secretion increased during culture, as well as under hormone stimulation on both days.

Response to hLH stimulation on $\mathrm{d} 6$ of culture in the two groups of patients is shown in Figure 3. In group 1, median testosterone secretion increased from 4.51 (basal median of five patients) to $13.5 \mathrm{pmol} / 10^{6}$ cells $\cdot d, p<0.01$. In group 2 , however, it changed from 1.95 (basal median of four patients) to 2.41 , the difference not being significant. Only one cell culture responded to hLH in this group. Under $\mathrm{hLH}$, there was a significant difference between groups 1 and $2, p<0.01$.

Response to hFSH stimulation by cells of group 1 is also shown in Figure 3. Median secretion of testosterone was significantly increased to $19.7 \mathrm{pmol} / 10^{6}$ cells·d $(p<0.01$ versus basal condition in the four patients). The effect of hFSH was not significantly different from that of hLH. Inspite of possible impurities in the pituitary preparation, no apparent difference was detected between the two FSH preparations used: 24.1 and $19.7 \mathrm{pmol} / 10^{6} \mathrm{cells} \cdot \mathrm{d}$ (means of two experiments) for highly purified and recombinant preparations, respectively.

Under rhGH stimulation, median testosterone secretion in group 1 was $11.9 \mathrm{pmol} / 10^{6} \mathrm{cells} \cdot \mathrm{d}$, significantly different from 


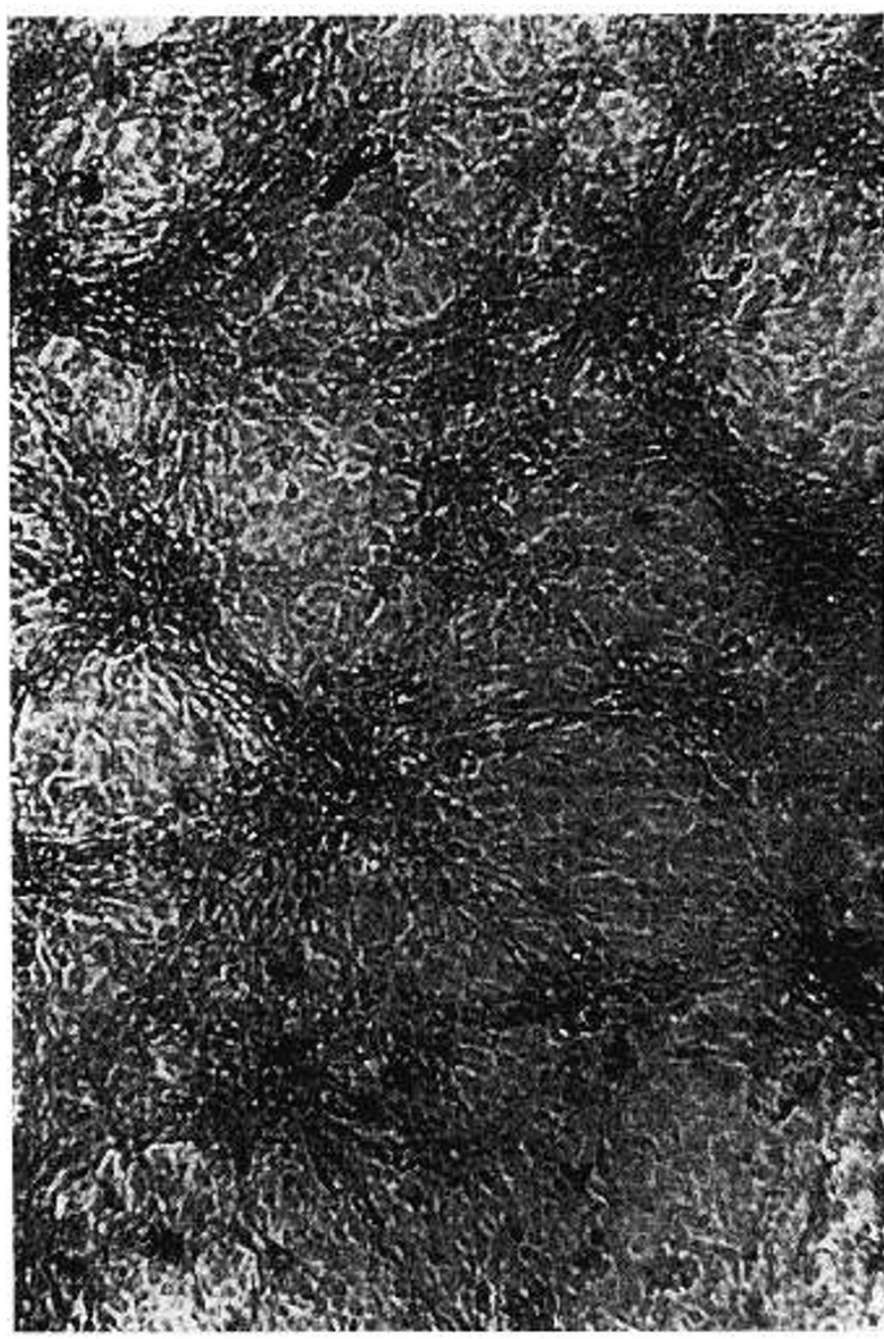

Figure 2. Histochemical staining for $3 \beta$-hydroxysteroid dehydrogenase of a cell monolayer on d 6 of culture. Fibroblast-like cells showing dark positive staining were arranged around clusters of negative staining cells $(\times 51)$.

Table 1. Testosterone secretion (pmol/10 $10^{6} \mathrm{cell} / \mathrm{d}$ ) on $d 4$ and on $d 6$ of culture by cells from a 1-mo-old subject, in basal conditions and under hormone stimulations ( $X \pm S E M$, in triplicate)

\begin{tabular}{ccc}
\hline Treatment & Day 4 & Day 6 \\
\hline Basal & $3.07 \pm 0.69$ & $7.15 \pm 2.04^{a}$ \\
hLH & $11.4 \pm 1.23^{b}$ & $30.3 \pm 2.57^{a, b}$ \\
hFSH & $18.7 \pm 3.11^{b}$ & $40.3 \pm 5.71^{a, b}$ \\
rhGH & $11.9 \pm 3.89^{b}$ & $34.0 \pm 5.43^{a, b}$ \\
\hline
\end{tabular}

${ }^{a}$ Significantly different from $\mathrm{d} 4(p<0.05)$.

${ }^{b}$ Significantly different from corresponding basal condition $(p<0.05)$.

basal conditions, $p<0.01$. In group 2 , however, it was only 1.96. Under thGH there was a significant difference between groups 1 and $2, p<0.01$ (Fig. 3).

\section{DISCUSSION}

This study confirms that prepubertal testicular cells obtained at necropsy can be maintained in culture in good functional conditions. They form a monolayer which presumably contains most testicular cells present in vivo. Using histochemical markers we have identified developing Sertoli cells and steroidogenic cells in the monolayers. In a previous report, we had also identified peritubular cells (18).

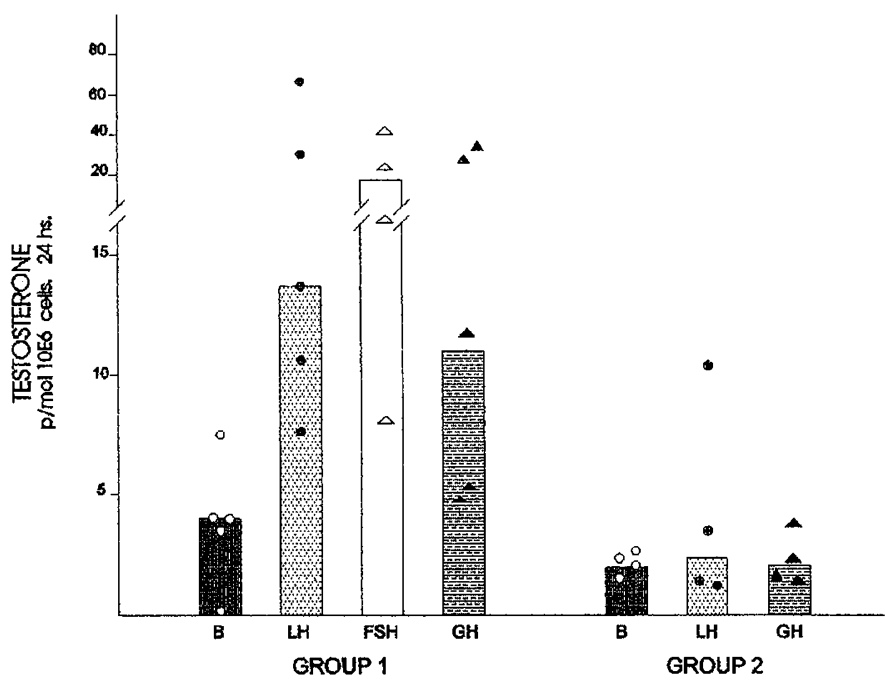

Figure 3. Secretion of testosterone into culture media ( $\mathrm{pmol} / 10^{6}$ cells $/ 24 \mathrm{~h}$ ), on $\mathrm{d} 6$ of culture in the two groups of patients under basal conditions, as well as under hLH, hFSH, and rhGH administration. Points represent individual data, columns represent medians.

We have observed that, in basal conditions and under $\mathrm{hLH}$, $\mathrm{hFSH}$, or rhGH stimulation, testosterone secretion in culture increased with time. This suggests that prepubertal steroidogenic cells undergo a process of differentiation in culture, even in the absence of gonadotropins. In a previous study (18) we had also observed a similar phenomenon in the presence of insulin.

The striking differences in testicular histology of the interstitium during the first years of life have prompted us to divide our clinical material into two age groups. Indeed, testosterone secretion by cells in culture reflected the steroidogenic potential of the testes in vivo, i.e. testosterone secretion in young infants during the first semester of life (group 1) is higher than in children at early childhood (group 2) (3), The high testosterone secretion of postnatal age has been attributed to stimulation of $\mathrm{LH}$ which also shows an increase during the first months of life (12). In our study, differences between the two groups were maintained when cells were cultured in the presence of hLH. Mature Leydig cell, and even mesenchymal precursors $(23,24)$, have the molecular machinery to respond to LH and to secrete testosterone. This suggests that testicular cells of group 1 had a higher density of LH responding cells. This is in agreement with what has been reported in vivo (9).

Surprisingly, when cells of patients of group 1 were stimulated with hFSH in the absence of hLH, they responded as though under hLH stimulation. Studies on the role of FSH in testicular steroidogenesis have been impaired because all preparations of hFSH used in the past have been contaminated with hLH. In two of our studies, using highly purified hFSH, bioactive hLH contamination was still present, but the dose of hFSH used contained an equivalent dose of hLH of only $0.0035 \mathrm{IU} / \mathrm{L}$. That the effect was not due to hLH contamination was confirmed by using rhFSH in two of the four experiments. Sertoli cells are the only cell type expressing FSH receptors in the testis. However, they lack the capacity to synthesize testosterone. Therefore, we propose that Sertoli cells responded to 
hFSH by secreting a factor(s) that stimulated neighboring Leydig cells to secrete testosterone. This mechanism might be operative in vivo, in normal children. There are in vitro evidences (22) that cocultures of immature pig Leydig and Sertoli cells secrete more testosterone than cultures of Leydig cells alone, indicating that there is a stimulating effect of Sertoli cells on Leydig cell function. IGF-I has been proposed as a candidate for this stimulatory effect (25), but other factors could be involved. Recent evidences of adult human Sertoli cell enhancement of Leydig cell testosterone secretion have also been reported (26).

Addition of rhGH, in the absence of $\mathrm{hLH}$, to cells of infants of group 1 increased testosterone secretion. This is in contrast to previous reports in cells of immature pigs (27). Differences in species, hGH preparation and degree of development can explain these different results. The effect of rhGH was similar to that of $\mathrm{hLH}$ and seemed to disappear in cells from older children. Specific receptors for GH and PRL have been described in the testis (28). However, the issue of the presence of $\mathrm{GH}$ receptors in the testis is controversial. Lobie et al. (29) detected strong $\mathrm{GH}$ receptor immunoreactivity in rat Leydig and Sertoli cells by specific immunohistochemistry but Tiong and Herington (30) could not detect GH receptor mRNA in rat testis by northern blotting. Mercado et al. (31) reported the expression of GH receptor mRNA in one human subject by reverse transcription-polymerase chain reaction. PRL binding sites have been described in rat Leydig cells (32). Finally PRL and $\mathrm{GH}$ receptor distribution include lymphatic and immune cells $(28,33)$ which are known to be present in the testis. Because hGH has both somatotropic and lactotropic activities (34), it is not possible to discern whether the biologic response detected resulted from an interaction of rhGH with GH or PRL receptors. The effect of $\mathrm{GH}$ that we have found in our studies suggests that either GH or PRL might have a physiologic role in testicular function of infants during the first semester of life. It is known that patients with GH deficiency (35) or GH insensitivity (36) have a remarkable delay in their sexual development. Whether this could be attributed to lack of GH action in the testes at early infancy remains to be shown. However, several studies in rodents (37-39) and in non-human primates (7) show that the secretory role of the neonatal testes is critical for normal CNS function in adulthood.

In summary, inasmuch as serum levels of $\mathrm{LH}, \mathrm{FSH}, \mathrm{GH}$, and PRL are higher during the first months of life than later in childhood, our studies support the possibility that the early postnatal activation of the testis is under multiple pituitary hormone influence.

Acknowledgments. The authors thank Diego Chirico for technical assistance and Elina Feinstein for secretarial help. We thank the National Pituitary Agency (U.S.) for the generous supply of hormone preparations. We also thank Drs. J. M. Saez and A. Solari for their helpful discussions.

\section{REFERENCES}

1. Prince FP 1990 Ultrastructural evidence of mature Leydig cells and Leydig cell regression in the neonatal human testis. Anat $\operatorname{Rec} 228: 405-417$
2. Reyes FI, Boroditsky RS, Winter JSD, Faiman C 1974 Studies on human sexual development. II. Fetal and maternal serum gonadotropin and sex steroid concentrations. J Clin Endocrinol Metab 38:612-617

3. Forest MG, Cathiard AM, Bertrand JA 1973 Evidence of testicular activity in early infancy. J Clin Endocrinol Metab 37:148-151

4. August GP, Grumbach MM, Kaplan SL 1972 Hormonal changes in puberty. III. Correlation of plasma testosterone, LH, FSH, testicular size, and bone age with male pubertal development. J Clin Endocrinol Metab 34:319-326

5. Swaab DF, Hofman MA 1988 Sexual differentiation of the human hypothalamus: ontogeny of the sexually dimorphic nucleus of the preoptic area. Dev Brain Res 537:141-148

6. Hutchison JB 1993 Aromatase: neuromodulator in the control of behaviour. J Steroid Biochem Mol Biol 44:509-520

7. Mann DR, Akinbanil MA, Gould KG, Tanner JM, Wallen K 1993 Neonatal treatment of male monkeys with a gonadotropin-releasing hormone agonist alters differentiation of central nervous system centers that regulate sexual and skeletal development. J Clin Endocrinol Metab 76:1319-1324

8. Eisler JA, Tannenbaum PL, Mann DR, Wallen K 1993 Neonatal testicular suppression with aGNRH agonist in rhesus monkeys: effects on adult endocrine function and behaviour. Horm Behav 27:551-567

9. Codesal J, Regadera J, Nistal M, Regadera-Cejas J, Paniagua R 1990 Involution of human fetal Leydig cells. An immunohistochemical, ultrastructural and quantitative study. J Anat 172:103-114

10. Hadziselimovic F 1977 Cryptorchidism. Ultrastructure of normal and cryptoechid testis development. Adv Anat Embryol Cell Biol 53:1-71

11. Nistal M, Paniagua R, Regadera J, Santamaria L, Amat P 1986 A quantitative morphological study of human Leydig cells from birth to adulthood. Cell Tissue Res 246:229-236

12. Winter JSD, Faiman C, Hobson WC, Prasad AV, Reyes FI 1975 Pituitary gonadal relations in infancy. I. Pattern of serum gonadotropin concentrations from birth to four years of age in man and chimpanzee. J Clin Endocrinol Metab 40:545-551

13. de Zegher F, Devlieger H, Veldhuis JD 1993 Properties of growth hormone and prolactin hypersecretion by the human infant on the day of birth. $J$ Clin Endocrinol Metab 76:1177-1181

14. Miller JD, Esparza A, Wright NM, Garimella V, Lai J, Lester SE, Mosier Jr HD 1993 Spontaneous growth hormone release in term infants: changes during the first four days of life. J Clin Endocrinol Metab 76:1058-1062

15. de Zegher F, Van den Berghe G, Devlieger H, Eggermont E, Veldhuis JD 1993 Dopamine inhibits growth hormone and prolactin secretion in the human newborn. Pediatr Res 34:642-645

16. Gluckman PD, Grumbach MM, Kaplan S 1981 The neuroendocrine regulation and function of growth hormone and prolactin in the mammalian fetus. Endocr Rev 2:363-395

17. Avallet O, Vigier M, Chatelain PG, Saez JM 1991 Regulation by growth factors of Leydig cell differentiated functions. Steroid Biochem Mol Biol 40:453-464

18. Berensztein E, Belgorosky A, Rivarola MA 1992 Primary culture of prepubertal human testicular cells isolated from testes collected at necropsy. Acta Endocrinol 127:66-71

19. Paranko J, Kallajoki M, Pillimiemi LJ, Lehto VP, Vintanem I 1986 Transient coexpression of cytokeratin and vimentin in differentiating rat Sertoli cells. Dev Biol 117:35-44

20. Steinberger E, Steinberger A, Vilar O 1966 Cytochemical study of $\Delta 5-3 \beta$ hydroxysteroid dehydrogenase in testicular cells grown in vitro. Endocrinology 79:406-410

21. Ausmüller G, Schulze C, Viebahn C 1992 Intermediate filaments in Sertoli cells Microsc Res Tech 20:50-72

22. Dixon WJ, Massey Jr FJ 1957 Introduction to Statistical Analysis, 2nd Ed. McGrawHill, New York, pp 295-297

23. Chemes HE, Gottlieb SE, Pasqualini T, Domenichini E, Rivarola MA, Bergada C 1985 Response to acute hCG stimulation and steroidogenic potential of Leydig cell fibroblast precursors in humans. J Androl 6:102-112

24. Chemes HE, Cigorraga S, Bergada C, Schteingart H, Rey R, Pellizzari E 1992 Isolation of human Leydig cell mesenchymal precursors from patients with androgens insensitivity syndrome: testosterone production and response to human chorionic gonadotropin stimulation in culture. Biol Reprod 46:793-801

25. Saez JM, Avallet O, Naville D, Perrard-Sapori MH, Chatelain PG 1989 SertoliLeydig cell communications. Ann NY Acad Sci 564:210-231

26. Lejeune H, Skalli M, Sanchez P, Avallet O, Saez JM 1993 Enhancement of testosterone secretion by normal adult human Leydig cells by co-culture with enriched preparations of normal adult human Sertoli cells. Int J Androl 16:27-34

27. Naville D, Chatelain PG, Avallet O, Saez JM 1990 Control of production of insulin-like growth factor $I$ by pig Leydig and Sertoli cells cultured alone or together. Cell-cell interactions. Mol Cell Endocrinol 70:217-224

28. Kelly PA, Djiane J, Postel-Vinay MC, Edery M 1991 The prolactin/growth hormone receptor family. Endocr Rev 12:235-251

29. Lobie PE, Breipohl W, Aragon AG, Waters MJ 1990 Cellular localization of the growth hormone receptor/binding protein in the male and female reproductive systems. Endocrinology 126:2214-2221

30. Tiong TS, Herington AC 1991 Tissue distribution, characterization and regulation of messenger ribonucleic acid for growth hormone receptor and serum binding protein in rat. Endocrinology 129:1628-1634

31. Mercado M, Davila N, McLeod JF, Baumann G 1994 Distribution of growth hormone receptor messenger ribonucleic acid containing and lacking exon 3 in human tissues. $\mathrm{J}$ Clin Endocrinol Metab 78:731-735 
32. Morris PL, Saxena BB 1980 Dose-and age-dependent effects of prolactin (PRL) on luteinizing hormone- and PRL-binding sites in rat Leydig cell homogenates. Endocrinology 107:1639-1645

33. Kies W, Butenant O 1995 Specific growth hormone receptors on human peripheral mononuclear cells: reexpression and characterization. J Clin Endocrinol Metab 60:740-746

34. Keeney D, Murry BA, Bartke A, Wagner TE, Mason JI 1993 Growth hormone transgenes regulate the expression of sex-specific isoforms of $3 \beta$-hydroxysteroid dehydrogenase $/ \Delta 5-4$ isomerase in mouse liver and gonads. Endocrinology 133:11311138

35. Bourguignon JP, Vandeweghe M, Vanderschueren-Lodeweyckx M, Malvaux P, Wolter R, Du Caju M, Ernould C 1986 Pubertal growth and final height in hypopytuitary boys: a minor role of bone age at onset of puberty. J Clin Endocrinol Metab $63: 376-382$
36. Savage MO, Blum WF, Ranke MB, Postel-Vinay MC, Cotterill AM, Hall K Chatelain PG, Preece MA, Rosenfeld RG 1993 Clinical features and endocrine status in patients with growth hormone insensitivity (Laron syndrome). J Clin Endocrinol Metab 77:1465-1471

37. Arnold AP, Gorski RA 1984 Gonadal Steroid induction of sex differences in the central nervous system. Annu Rev Neurosci 7:413-442

38. Rhees RW, Shryne JE, Gorski RA 1990 Termination of the hormone-sensitive period for differentiation of the sexually dimorphic nucleus of the preoptic area in male and female rats. Dev Brain Res 52:17-23

39. Merchenthaler I, Lennard DE, Lopez FJ, Negro-Vilar A 1993 Neonatal imprinting predetermines the sexually dimorphic estrogen-dependent expression of galanin in luteinizing hormone-releasing hormone neurons. Proc Natl Acad Sci USA 90:10479_ 10483 